\title{
Рыжкова O.A. \\ Роль тренинга в развитии эмпатии студентов-психологов как фактора, определяющего личностные особенности, повышающие вероятность успешности в профессиональной деятельности
}

ОГАО ДПО «Белгородский институт развития образования»

(Россия, Белгород)

doi: 10.18411/trnio-11-2021-217

\section{Аннотация}

К личностным профессионально важным качествам (ПВК) студентов-психологов относятся такие качества как социально-коммуникативные ПВК; качества, определяющие «Я-концепцию» личности, уровень эмпатии, креативность. В данной статье рассматривается роль тренинга в развитии эмпатии студентов-психологов как фактора, определяющего профессиональную компетентность будущих специалистов.

Ключевые слова: профессионально важные качества, эмпатия, тренинг, программа тренинга, методика И.М. Юсупова, студенты-психологи, профессиональная компетенция.

Abstract

The personal professionally important qualities (PIQ) of psychology students include such qualities as social and communicative PIQ; qualities that determine the "I-concept" of personality, the level of empathy, creativity. This article examines the role of training in the development of empathy of psychology students as a factor determining the professional competence of future specialists.

Keywords: professionally important qualities, empathy, training, training program, methodology of I.M. Yusupov, psychology students, professional competence.

Психологическая наука, как отмечает В.В. Рубцов, становится неотъемлемой составляющей современной социальной практики, ее системообразующим ядром [1]. В ответ на социальные изменения в нашей стране востребованность профессии «психолог» в последнее время возрастает. Комплекс разнообразных проблем, затрагивающих медицину, образование, политику, предпринимательство и т.д. нельзя решить без участия высоко квалифицированного, грамотного психолога. Каждый психолог в процессе своей профессиональной деятельности должен обладать целым рядом личностных профессионально-важных качеств, являющихся необходимым условием формирования и развития профессиональной сферы. Специалисту крайне важно непрерывно совершенствовать свои профессиональные умения и навыки, выстраивая грамотный профиль развития своей психологической культуры.

Перед высшими учебными заведениями РФ стоит одна из важнейших задач, заключающаяся в создании благоприятных, эффективных условий для становления и развития целеустремленной личности, обладающей высоким уровнем профессионального мышления, способной конструктивно решать сложные задачи в постоянно меняющемся социальном климате. Необходимо не просто предоставлять студенту соответствующие знания, умения и навыки, но и активно содействовать процессу формирования и непрерывного развития творческого, не стандартно думающего специалиста, обладающего критическим мышлением, способного эффективно адаптироваться к разнообразным преобразованиям российского общества.

Выпускники высших учебных заведений по направлению подготовки «Психология» должны обладать личностными профессионально важными качествами, позволяющими успешно интегрироваться в профессиональную область деятельности, активно приспосабливаться к социальным трансформациям и изменениям, искренне любящих свою работу и уважающих своих клиентов. 
До сих пор в научном обществе нет однозначного подхода в определении основных характеристик и функций профессионала-психолога, что отражается в наличии проблем разработки единой концепции подготовки профессионального психолога в образовательных учреждениях [2]. Вопросами изучения профессионально важных качеств психологов занимались Г.С. Абрамова, У. Глассер. В.Н. Карандышев, Р.Б. Кеттелл, А.Г. Лидерс, Р.В. Овчарова, А.А. Осипова, Е.В. Сидоренко, Н.Ю. Хрящева и др. В своих трудах Деркач А.А. отмечает, что специфические для профессии психолога качества проявляются в сформированности всех компонентов психики профессионала - психических процессов, свойств, состояний, которые позволяют ему выполнять избранную деятельность [2]. Стоит отметить проведенный на сайте www. futurejob.ru опрос среди практикующих психологов, целью которого было выявление основных качеств, необходимых профессиональному психологу в рамках реализации своей трудовой деятельности. Опрошенные специалисты выделили не так уж много соответствующих качеств, остальные качества они назвали профессиональными навыками, формирующимися в ходе образовательного процесса и конкретной практики. Привлекает внимание, что психологи однозначно отметили важнейшую, фундаментальную особенность успешного психолога (вне зависимости от выбранной специализации) - интерес и уважение к Человеку, определяющие эффективность результатов профессиональной сферы [3].

Проанализировав источники литературы и два профессиональных стандарта, соответствующих профессиональной деятельности выпускников, освоивших программу бакалавриата по направлению подготовки 37.03.01 (профессиональные стандарты «Педагогпсихолог» (психолог в сфере образования), «Психолог в социальной сфере») [4, 5], можно сделать выводы об общем перечне личностных профессионально важных качествах (ПВК), необходимых для профессиональной деятельности будущих психологов, формирующихся и развивающихся в рамках образовательного процесса университета. К таким личностных ПВК следует отнести социально-коммуникативные ПВК; качества, определяющие «Яконцепцию» личности, уровень эмпатии, креативность. В данной статье рассматривается роль тренинга в развитии эмпатии студентов-психологов как фактора, определяющего профессиональную компетентность будущих специалистов психологов.

Нами была разработана и апробирована программа психологического тренинга развития личностных профессионально важных качеств студентов-психологов, включающий в себя следующие направления работы: тренинг командообразования; тренинг развития социально-коммуникативных умений; тренинг самопознания (развития «Я»-концепции); тренинг эмпатии; тренинг развития умений эффективного поведения в конфликтных ситуациях.

В качестве эмпирической базы исследования выступила Автономная некоммерческая организация высшего образования «Белгородский университет кооперации, экономики и права». В исследовании приняли участие студенты I-IV курсов очной формы обучения по направлению подготовки бакалавриата «Психология» (профиль «Социальная психология») в количестве 40 человек. Возраст обучающихся 18-23 года.

Программа тренинга рассчитана на встречи два раза в неделю в течение учебного года. Занятия проводились для студентов-психологов I-IV курсов, обучавшихся на очной форме обучения. Общее количество участников составило 40 человек. Смешанная группа делилась на две подгруппы, для каждой из которых тренинг проводился в свое назначенное время. Занятия проходили в рамках реализации работы студенческого научного кружка «Мир психологических знаний» в свободное от учебных занятий время. Одно занятие занимало примерно 1,5-2 ч.

Целью тренинга стало развитие личностных профессионально важных качеств (ПВК), значимые для эффективного включения студента-психолога в практическую деятельность. Задачи тренинга: осуществить эффективный процесс развития социально-коммуникативных качеств; ПВК, определяющие «Я»-концепцию личности, уровень эмпатии, креативность; проследить динамику перечисленных выше ПВК.

Реализация программы тренинга основывалась на теории П.Я. Гальперина, рассматривающего активность личности с позиций деятельности, эффективно 
способствующей развитию личностных качеств [6]. В рамках проведения занятий со студенами-психологами данной деятельностью стали тренинговые упражнения, подобранные в соответствии с вышеуказанной целью [6].

Рассмотрим динамику показателей ответов студентов-психологов по итогам прохождения методики И.М. Юсупова «Диагностика уровня эмпатии» до применения тренинга и после. В результате обработки данных были получены средние баллы уровней эмпатии студентов-психологов I-IV курсов (таблицы 1, 2). С помощью t-критерия Стьюдента показаны неслучайные, достоверные различия между показателями до применения тренинга и после. Различия в показателях уровней эмпатии статистически значимы на уровне достоверности $p \leq 0,05$ по t-критерию Стьюдента. Наглядное изображение результатов представлено на рис. 1.

Таблича 1

Средние балль результатов студентов-психологов I-IV курсов по итогам прохождения методики И.М. Юсупова «Диагностика уровня эмпатии»

\begin{tabular}{|c|c|c|c|}
\hline $\begin{array}{l}\text { Средний балл } \\
\text { до тренинга }\end{array}$ & $\begin{array}{c}\text { Средний балл } \\
\text { после тренинга }\end{array}$ & \multicolumn{2}{|c|}{ Значимые различия, $p$} \\
\hline 38,7 & 58,2 & \multirow[b]{2}{*}{$0,000^{*}$} & \multirow[b]{2}{*}{ Есть различия, + } \\
\hline $\begin{array}{c}\text { Нормальныий уровень } \\
\text { эмпатии }\end{array}$ & Нормальный уровень эмпатии & & \\
\hline
\end{tabular}

Примечание: "

Таблииа 2

Результаты студентов-психологов I-IV курсов по итогам прохождения методики И.М.

Юсупова «Диагностика уровня эмпатии»

\begin{tabular}{|c|c|c|}
\hline \multirow{2}{*}{ Уровень эмпатии } & \multicolumn{2}{|c|}{ Количество студентов, \% } \\
\cline { 2 - 3 } & До тренинга & После тренинга \\
\hline Очень высокий & 0 & 22,5 \\
\hline Высокий & 0 & 77,5 \\
\hline Нормальньй & 67,5 & 0 \\
\hline Низкий & 32,5 & 0 \\
\hline Очень низкий & 0 & 0 \\
\hline
\end{tabular}

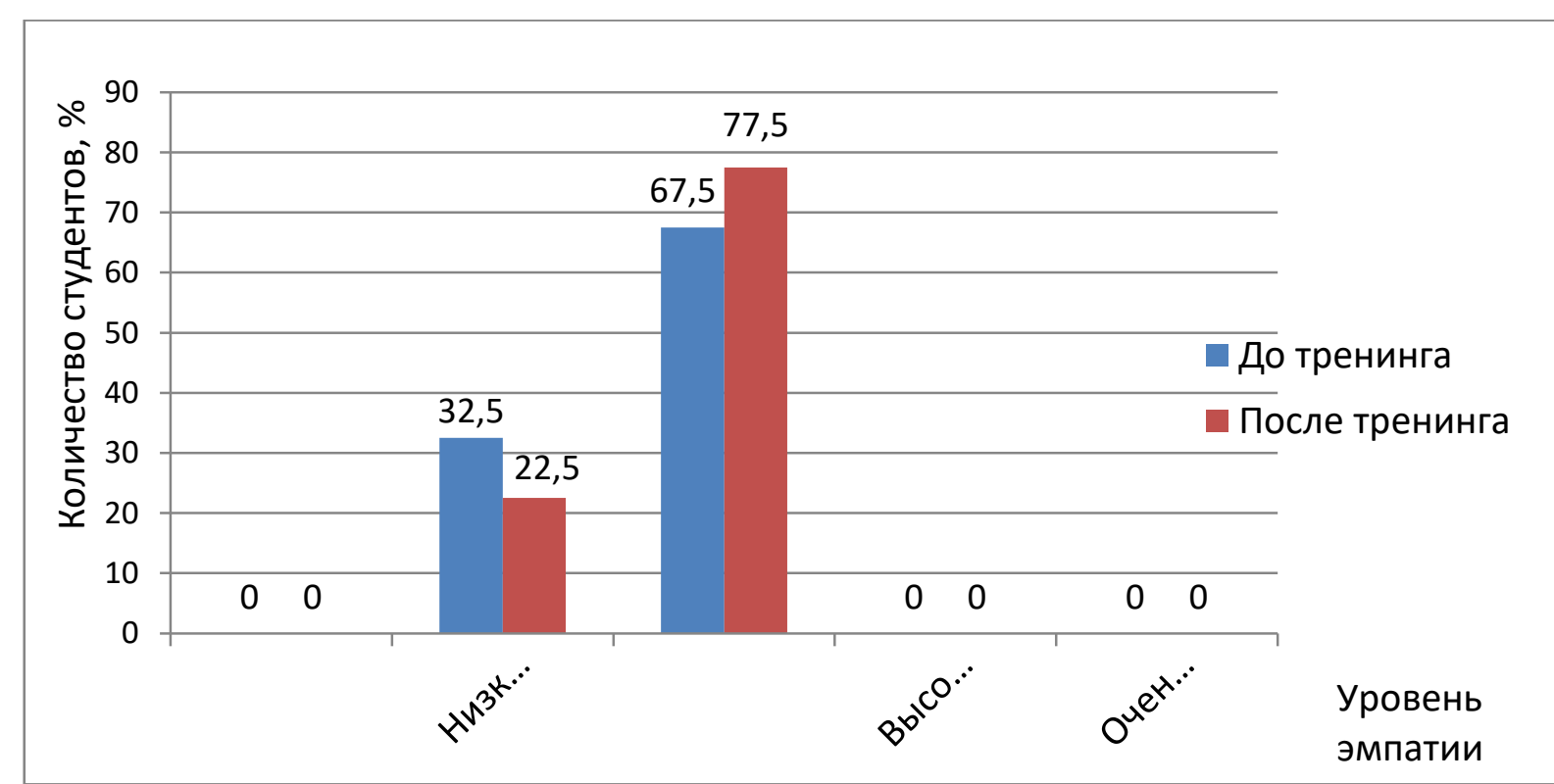

Рисунок 1. Результаты студентов-психологов I-IV курсов по итогам прохождения методики И.М. Юсупова «Диагностика уровня эмпатии»

Из приведенных выше табл. 1, 2 и рис. 1 следует, что у студентов-психологов I-IV курсов как до тренинга, как и после тренинга, лидирующий уровень эмпатии - нормальный. Общий средний балл результатов обучающихся до применения тренинга - 38,7, что соответствует значениям нижней границы нормального уровня эмпатии (от 37 до 62 баллов). 
После проведения тренинга общий средний балл ответов студентов-психологов повысился до значения 58,2 и находится ближе к значениям высшей границы нормального уровня эмпатии. Как видно из табл. 1, обнаружены статистически значимые различия между результатами диагностики до применения тренинга и после $\left(\mathrm{p} \leq 0,001^{* *}\right)$, что отражается в росте показателей нормального уровня эмпатии и показывает качественные положительные изменения в эмоциональной сфере обучающихся.

Результаты диагностики говорят о развитии у студентов умений общения с окружающими людьми, сопереживания, что в целом способствует адекватным межличностным отношениям. Однако в рамках нормального уровня эмпатии автором методики отмечается наличие затруднений в прогнозировании развития отношений между людьми, отсутствие раскованности чувств, что влияет на полноценное восприятие людей.

Таким образом, в рамках реализации тренинга создаются условия для апробирования нового опыта во взаимосвязи с уже имеющимися собственными практическими умениями и навыками, происходит преобразование стереотипов мышления с вплетением новых подходов и путей реализации личности в разнообразных профессиональных ситуациях. Тренинг эффективно способствует самораскрытию, самовыражению каждого участника, возможности адекватного преодоления затруднительных ситуаций, что выражается в расширении границ восприятия и обогащения внутреннего личного опыта. По сравнению с традиционными репродуктивными методами обучения тренинг создает необходимые оптимальные психолого-педагогические условия для повышения уровня эмпатии студентов-психологов, формирования и развития целостного системного мышления будущих специалистов психологов, их профессиональной компетентности.

$$
* * *
$$

1. Фомина, Л. Ю. Развитие профессионально-важных качеств студентов в процессе профессионального обучения / Л. Ю.Фомина. - Текст : непосредственный // Ученые записки. - 2009. - Т 2, Сер. Психология. Педагогика. № 2 (6). - С. 48-51.

2. Килинская, Н.В.Представления студентов о профессионально важных качествах психолога в процессе обучения в вузе / Н. В. Килинская. - Текст : непосредственный // Молодой ученый. Психологические науки. Теория и практика. - 2015. - №4. - С. 36-39.

3. Ж Жуматаева, М.С. Профессионально-важные качества будущих психологов / М. С. Жуматаева, М. К Бапаева. - Текст : непосредственный // Достижения науки и образования. - 2015. - №1 (1). - С. 58-61.

4. Профессиональный стандарт РФ «Педагог-психолог (психолог в сфере образования» : издание официальное : утвержден и введен в действие приказом Министерством труда и социальной защиты Российской Федерации от 18.08.2015г. № 514н. - Москва : Стандартинформ, 2019. - Текст : непосредственный.

5. Профессиональный стандарт РФ «Пихолог с социальной сфере»: издание официальное : утвержден и введен в действие приказом Министерством труда и социальной защиты Российской Федерации от 18.10.2013г. № 682н. - Москва :Стандартинформ, 2019. - Текст : непосредственный.

6. Рожкова, А.П. Развитие личностных профессионально важных качеств студентов-психологов средствами тренинга : автореф. дис. канд. психолог.наук; Казань, гос. техн. унт им. А.Н. Туполева / А.П. Рожкова. Казань, 2004. - 22 с. - Текст : непосредственный.

\section{Шохова Ю.С., Орлова Л.В. \\ Аэропорт Бен-Гуриона в Израиле, или безопасности много не бывает \\ ФГБОУ ВО «Ульяновский институт гражданской авиаџии имени Главного маршала авиации Б.П.Бугаева» \\ (Россия, Ульяновск)}

doi: 10.18411/trnio-11-2021-218

Научный руководитель: Орлова Л.В.

\section{Аннотация}

Работа посвящена изучению безопасности на воздушном транспорте на примере аэропорта Бен-Гуриона. Проанализирована статистика авиационных происшествий Израиля, 